\title{
Loneliness in senescence and its relationship with depressive symptoms: an integrative review
}

Letícia Menezes de Oliveira' $\mathbb{D}$ Gesualdo Gonçalves de Abrantes' (ID Gérson da Silva Ribeiro² Nilza Maria Cunha ${ }^{3}$ ID Maria de Lourdes de Farias Pontes ${ }^{3}$ (D) Selene Cordeiro Vasconcelos ${ }^{3}$ (D)

\section{Abstract}

The increase in life expectancy and the percentage increase in the older population are related to the reduction in quality of life and social life due to the biopsychosocial changes inherent to the aging process. The present study aimed to verify scientific evidence on the relationship between loneliness and depressive symptoms among older adults. An integrative review was carried out using the following databases: SCOPUS, PubMed, Medline, Web of Science, CINAHL and PyscINFO, applying the descriptors indexed in the Mesh Terms and DeCS "aged", "loneliness", "depression". The PICOS strategy was used to prepare the title and guiding question and the PRISMA methodological guidelines were used to write the report of this review. A total of 827 articles were identified, of which 23 were selected, 16 from the database and seven through a reverse search. Loneliness and depression have some characteristics in common, so that when one of these conditions develops in older adults, another is stimulated. Thus, loneliness is a major risk factor for the development of depression, just as depression is an aggravating factor for loneliness in older adults.

Keywords: Aging. Health of the Elderly. Loneliness. Depression.

\footnotetext{
Universidade Federal da Paraíba, Departamento de Enfermagem. João Pessoa, PB, Brasil.

Universidade Federal da Paraíba, Departamento de Enfermagem Clínica. João Pessoa, PB, Brasil.

Universidade Federal da Paraíba, Departamento de Enfermagem em Saúde Coletiva. João Pessoa, PB, Brasil.
} 


\section{INTRODUCTION}

Senescence is characterized as a natural process of human aging, and its percentage increase has arisen from the exodus of the population from rural areas and the reduction in the infant mortality rate ${ }^{1}$ However, the growth of the older population and increased life expectancy has resulted in psychological consequences, examples of which are depression and feelings of loneliness.

According to $\mathrm{PAHO} / \mathrm{WHO}^{2}$ data, depression is the main cause of social disability, affecting approximately 300 million people worldwide. In terms of its prevalence among the older population, a study found that about $30 \%$ of participants exhibited signs and symptoms of depression ${ }^{3}$.

Depression is diagnosed when the individual has at least five specific symptoms of the disease for a minimum of two weeks, including: depressed mood, decreased interest in most activities, weight gain or loss equivalent to $5 \%$ of body weight, insomnia or hypersomnia, fatigue, feelings of worthlessness or guilt, reduced concentration and suicidal ideation, without an association with mourning or a medical condition $^{4}$.

Loneliness can manifest itself through the following aspects: absence of purpose and meaning in life, emotional reactions, undesirable and unpleasant feelings, feelings of isolation and separation, deficiency in relationships and a lack of intimacy, and detachment ${ }^{5}$. A study showed that $35.7 \%$ of older adults surveyed said they felt loneliness at different levels of intensity, varying from some to many times ${ }^{6}$.

Given the prevalence of depressive symptoms and feelings of loneliness in the older population, the present study sought to consider the following question: what is the relationship between loneliness and depressive symptoms in older adults? Therefore, the objective was to verify the scientific evidence on the relationship between loneliness and depressive symptoms in older adults.

\section{METHOD}

An integrative literature review was performed using articles that addressed the theme of the relationship between loneliness and depressive symptoms in older adults.

The databases used were: SCOPUS, PubMed, Medline, Web of Science, CINAHL and PyscINFO, as these are considered important scientific bases of international scope. It was decided not to limit based on the year of publication of the articles, expanding the results of the study, in which articles published between the years 2000 and 2019 were included.

The inclusion criteria for the sample were: articles that addressed the theme of loneliness and depressive symptoms. The exclusion criteria were literature review articles. The following descriptors indexed in Mesh Terms and DeCS were used: "Aged" AND "Loneliness" AND "Depression”.

The process of eligibility of articles for the sample of the present review followed three stages: reading of titles, to assess if meets theme of depression and loneliness in older adults; reading of abstract to investigate the suitability of the article for answering the research question; and reading of the full articles in order to extract the data for summarization of the outcomes. All articles included in the sample addressed loneliness and depressive symptoms in older people and the data were analyzed using the results.

In addition, a reverse search, consisting of searching for articles based on a survey of the references of the articles selected for the sample, was performed in order to broaden the search and diversify the results.

The study was prepared using the PRISMA method, which contains 27 criteria that must be applied in bibliographic reviews ${ }^{7}$. The PRISMA diagram shows the step-by-step selection in a summarized manner, from the retrieval of articles in the databases to their subsequent inclusion (Figure 1). 
What is the relationship between loneliness and depressive symptoms in older adults?

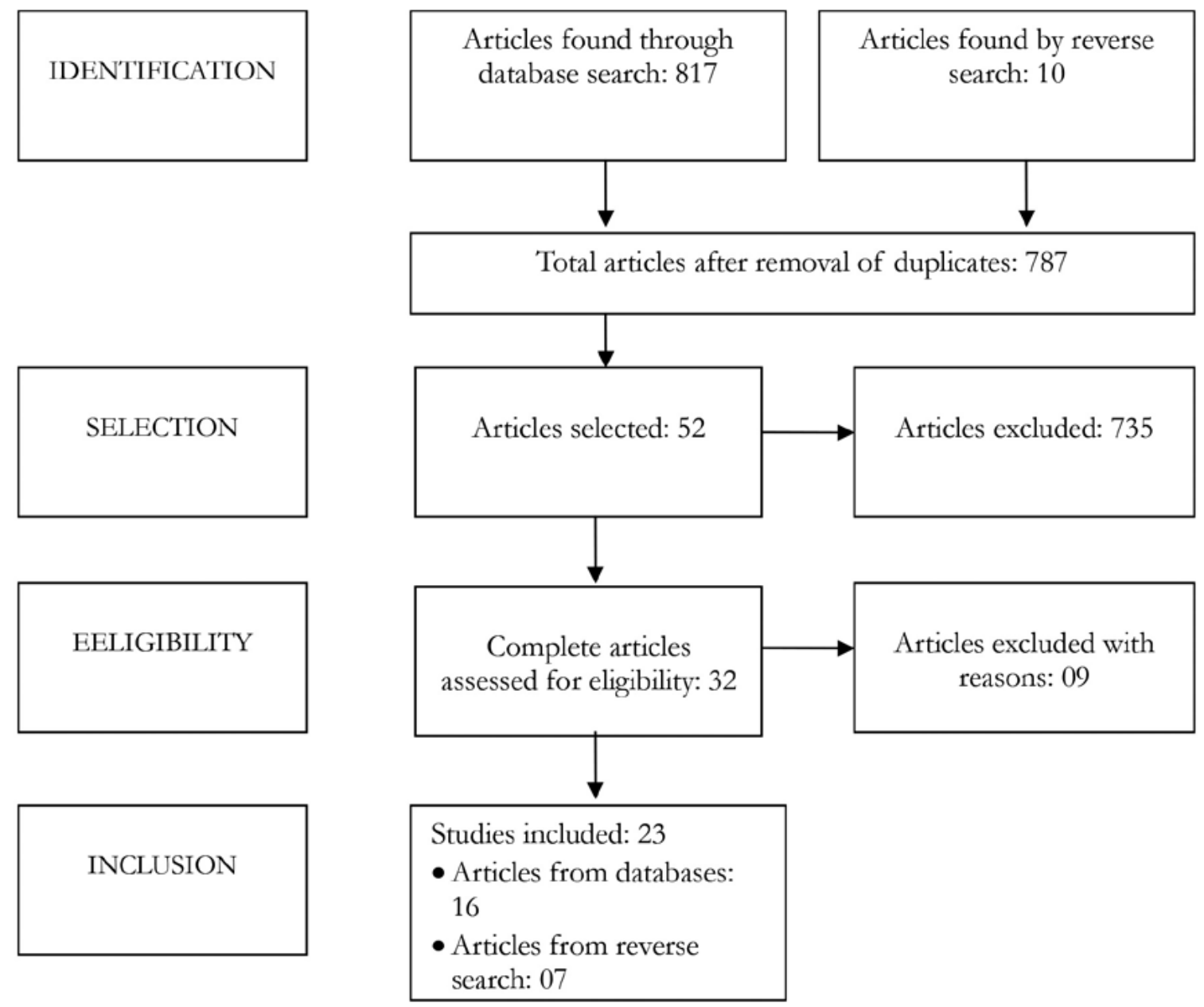

Figure 1. Flowchart of article selection process based on the PRISMA7 method. Paraíba, 2019.

\section{RESULTS}

The searches in the databases retrieved a total of 817 publications, with 23 articles selected for the sample, of which 16 came from the databases and seven were retrieved through reverse search. The general panorama of publications shows the majority of articles were published in journals specializing in mental health. There has also been an increase in research on this topic in recent years, with 14 articles published between 2010 and 2019 addressing depressive symptoms and loneliness in aging.

As for the origin of the studies, the articles used for the sample were from Europe $(n=09)$, Asia $(\mathrm{n}=07)$, North America $(\mathrm{n}=05)$, Oceania $(\mathrm{n}=01)$ and South America ( $\mathrm{n}=01)$.

Table 1 summarizes the general information contained in the articles included in the sample. 
Table 1. Overall characteristics of articles selected for sample, $(n=28)$. Paraíba, 2019.

\begin{tabular}{|c|c|c|c|}
\hline Author/Year & $\begin{array}{l}\text { Methodological } \\
\text { design }\end{array}$ & Sample & Main Results \\
\hline $\begin{array}{l}\text { Chou, K. L.; Chi, I.; } \\
\text { Boey, K. W. }{ }^{16} \\
2000\end{array}$ & $\begin{array}{l}\text { Cross-sectional } \\
\text { study. }\end{array}$ & 1,106 older adults. & $\begin{array}{l}\text { Older adults living alone (social loneliness) report } \\
\text { more depressive symptoms. }\end{array}$ \\
\hline $\begin{array}{l}\text { Ramos, M.; Wilmoth, } \\
{\mathrm{J} \cdot{ }^{27}} 2003\end{array}$ & $\begin{array}{l}\text { Cross-sectional } \\
\text { study. }\end{array}$ & 871 older adults. & $\begin{array}{l}\text { A lack of social integration increases depressive } \\
\text { symptoms and social integration reduces depressive } \\
\text { symptoms. }\end{array}$ \\
\hline $\begin{array}{l}\text { Alpass, F. M.; Neville, } \\
\text { S. }^{8} \\
2003\end{array}$ & $\begin{array}{l}\text { Cross-sectional } \\
\text { study. }\end{array}$ & 217 older adults. & Lonely men have higher scores on the GDS scale. \\
\hline $\begin{array}{l}\text { Chou, K. L.; Chi, I. }{ }^{11} \\
2004\end{array}$ & $\begin{array}{l}\text { Cross-sectional } \\
\text { study. }\end{array}$ & 1,903 older adults. & $\begin{array}{l}\text { Loneliness was associated significantly and } \\
\text { positively with depression. }\end{array}$ \\
\hline $\begin{array}{l}\text { Adams, K. B.; } \\
\text { Sanders, S.; Auth, E. }{ }^{15} \\
2004\end{array}$ & $\begin{array}{l}\text { Cross-sectional } \\
\text { study. }\end{array}$ & $\begin{array}{l}\text { Older adults aged } \\
\text { between } 60 \text { and } \\
98 \text { years. }\end{array}$ & $\begin{array}{l}\text { Not everyone who is lonely is depressed. } \\
\text { Loneliness is not a determinant of depression, but } \\
\text { it is a risk. }\end{array}$ \\
\hline $\begin{array}{l}\text { Stek, M. L. }{ }^{14} \\
2005\end{array}$ & $\begin{array}{l}\text { Longitudinal } \\
\text { study. }\end{array}$ & $\begin{array}{l}476 \text { older adults } \\
\text { aged } 85 .\end{array}$ & $\begin{array}{l}\text { Those who suffered from depression and feelings } \\
\text { of loneliness had a } 2.1 \text { times greater risk of } \\
\text { mortality. }\end{array}$ \\
\hline $\begin{array}{l}\text { Tiikkainen, P.; } \\
\text { Heikkinen, R. L. } \\
2005\end{array}$ & $\begin{array}{l}\text { Longitudinal } \\
\text { study. }\end{array}$ & $\begin{array}{l}207 \text { older adults } \\
\text { aged } 80 \text { and } 133 \\
\text { aged } 85 \text {. }\end{array}$ & $\begin{array}{l}\text { In women, depressive symptoms predict greater } \\
\text { loneliness than in men; those who were lonely were } \\
\text { more depressed and had less social interaction. }\end{array}$ \\
\hline $\begin{array}{l}\text { Paul, C.; Ayis, S.; } \\
\text { Ebrahim, S. } \\
2006\end{array}$ & $\begin{array}{l}\text { Cross-sectional } \\
\text { study. }\end{array}$ & 999 older adults. & $\begin{array}{l}\text { People who live alone or feel lonely had higher } \\
\text { rates of psychological distress. }\end{array}$ \\
\hline $\begin{array}{l}\text { Barg, F. K. et al. }{ }^{19} \\
2006\end{array}$ & $\begin{array}{l}\text { Cross-sectional } \\
\text { study. }\end{array}$ & 102 older adults. & $\begin{array}{l}\text { Older adults participating in the study reported } \\
\text { that loneliness is a precursor to depression and } \\
\text { anxiety. }\end{array}$ \\
\hline $\begin{array}{l}\text { Aylaz, R., et al. }{ }^{9} \\
2012\end{array}$ & $\begin{array}{l}\text { Descriptive } \\
\text { study. }\end{array}$ & $\begin{array}{l}17,080 \text { older } \\
\text { adults. }\end{array}$ & $\begin{array}{l}\text { There was a positive correlation between geriatric } \\
\text { depression and loneliness. }\end{array}$ \\
\hline $\begin{array}{l}\text { Tsai, F. J.; Motamed, } \\
\text { S.; Rougemont, A. } \\
2013\end{array}$ & $\begin{array}{l}\text { Longitudinal } \\
\text { study. }\end{array}$ & $\begin{array}{l}\text { Individuals aged } \\
50 \text { and above. }\end{array}$ & $\begin{array}{l}\text { Older people who live without a partner, without } \\
\text { children or who do not provide care to their } \\
\text { grandchildren are at greater risk of feeling lonely } \\
\text { and depressed. }\end{array}$ \\
\hline $\begin{array}{l}\text { Dahlberg, l., et al. }{ }^{26} \\
2014\end{array}$ & $\begin{array}{l}\text { Longitudinal } \\
\text { study. }\end{array}$ & $\begin{array}{l}\text { Older adults aged } \\
76 \text { and above. }\end{array}$ & $\begin{array}{l}\text { The increase in depression and recent widowhood } \\
\text { were significant predictors of loneliness. }\end{array}$ \\
\hline $\begin{array}{l}\text { Houtjes, W., et al. }{ }^{24} \\
2014\end{array}$ & $\begin{array}{l}\text { Longitudinal } \\
\text { study. }\end{array}$ & $\begin{array}{l}\text { Older adults } \\
\text { with depressive } \\
\text { symptoms. }\end{array}$ & $\begin{array}{l}\text { Depression has been associated with higher levels } \\
\text { of loneliness over time, especially in men and older } \\
\text { adults. }\end{array}$ \\
\hline $\begin{array}{l}\text { Kvaal, K.; Halding, A. } \\
\text { G.; Kvigne, K. }{ }^{30} \\
2014\end{array}$ & $\begin{array}{l}\text { Comparative } \\
\text { study. }\end{array}$ & 101 older adults. & $\begin{array}{l}18 \% \text { of older adults who felt lonely were diagnosed } \\
\text { with depression. Loneliness was related to the } \\
\text { feeling of emptiness and negative emotions. }\end{array}$ \\
\hline $\begin{array}{l}\text { Navarro, J. R.; Benito- } \\
\text { Leon, J.; Olazaran, K. } \\
\text { A. P. }{ }^{12} \\
2015\end{array}$ & $\begin{array}{l}\text { Cross-sectional } \\
\text { study. }\end{array}$ & 1,126 older adults. & $\begin{array}{l}\text { Lack of social support and loneliness were } \\
\text { identified as factors that favor the onset of } \\
\text { depressive symptoms. Widowhood and living alone } \\
\text { are risk factors for depression. }\end{array}$ \\
\hline $\begin{array}{l}\text { Li, J.; Theng, Y. L.; } \\
\text { foo, S. }{ }^{10} \\
2015\end{array}$ & $\begin{array}{l}\text { Cross-sectional } \\
\text { study. }\end{array}$ & 162 older adults. & $\begin{array}{l}\text { Among the main psychosocial factors, loneliness } \\
\text { has a stronger association with geriatric depression. }\end{array}$ \\
\hline
\end{tabular}


Continuation of Table 1

\begin{tabular}{|c|c|c|c|}
\hline Author/Year & $\begin{array}{l}\text { Methodological } \\
\text { design }\end{array}$ & Sample & Main Results \\
\hline $\begin{array}{l}\text { Fried, E. I., et al. }{ }^{17} \\
2015\end{array}$ & $\begin{array}{l}\text { Longitudinal } \\
\text { study. }\end{array}$ & $\begin{array}{l}1,532 \text { married } \\
\text { older adults. }\end{array}$ & $\begin{array}{l}\text { Grieving for a spouse mainly affected loneliness, } \\
\text { which in turn activated other depressive symptoms. }\end{array}$ \\
\hline $\begin{array}{l}\text { Holvast, F., et al. }{ }^{34} \\
2015\end{array}$ & Cohort study. & $\begin{array}{l}\text { Individuals } \\
\text { between } 60 \text { and } \\
90 \text { of age with } \\
\text { major depression, } \\
\text { dysthymia or } \\
\text { minor depression. }\end{array}$ & $\begin{array}{l}\text { Lonely respondents had fewer social networks and } \\
\text { experienced more severe depressive symptoms. }\end{array}$ \\
\hline $\begin{array}{l}\text { Holwerda, T. J., et al. } \\
2016\end{array}$ & Cohort study. & $\begin{array}{l}2,878 \text { individuals } \\
\text { between } 55 \text { and } \\
85 \text { years old. }\end{array}$ & $\begin{array}{l}\text { Women suffer more emotional loneliness and men, } \\
\text { more social loneliness. Depression was associated } \\
\text { with premature death in men, with higher mortality } \\
\text { in the group of lonely people. }\end{array}$ \\
\hline $\begin{array}{l}\text { Wong, N. M. L., et } \\
\text { al. }^{25} \\
2016\end{array}$ & $\begin{array}{l}\text { Cross-sectional } \\
\text { study. }\end{array}$ & 54 older adults. & $\begin{array}{l}\text { Loneliness was a determinant of the negative } \\
\text { affective processing of delayed depression. }\end{array}$ \\
\hline $\begin{array}{l}\text { Fernandes, S.; } \\
\text { Davidson, J. G. S.; } \\
\text { Guthrie, D. M. } \\
2017\end{array}$ & Cohort study. & $\begin{array}{l}2,499 \text { severely ill } \\
\text { older adults. }\end{array}$ & $\begin{array}{l}\text { Worsening symptoms of depression, declining } \\
\text { social activities and not living with a primary } \\
\text { caregiver increase the risk of loneliness. }\end{array}$ \\
\hline $\begin{array}{l}\text { Wang, G. et al. }{ }^{13} \\
2017\end{array}$ & Cluster trial. & $\begin{array}{l}814 \text { older adults } \\
\text { with at least one } \\
\text { child. }\end{array}$ & $\begin{array}{l}\text { Loneliness from empty nest syndrome leads to } \\
\text { symptoms and major depressive episodes. }\end{array}$ \\
\hline $\begin{array}{l}\text { Conde-Sala, J. L. et } \\
\text { al. }^{31} \\
2019\end{array}$ & Cohort study. & $\begin{array}{l}31,491 \text { older } \\
\text { adults. }\end{array}$ & $\begin{array}{l}\text { One of the risk factors associated with depressive } \\
\text { symptoms was loneliness and the female gender. }\end{array}$ \\
\hline
\end{tabular}

Regarding the method used and the type of study, there was a predominance of quantitative studies that evaluated the depressive symptoms and loneliness of older adults through depression and/or loneliness scales, in addition to interviews or questionnaires. Among the scales most used in the articles were the Geriatric Depression Scale (GDS) ${ }^{8-15}$ and the Center for Epidemiological Scale Depression scale (CES-D) 16-21 for depression, and the scale of the University of California, Los Angeles (UCLA) 8-10,13,15 for loneliness.

The minimum age of the participants in most articles included in the sample was 60. However, some articles studied people below this age group, but were not excluded from the sample of this review because they included older adults in their sample.

\section{DISCUSSION}

The analysis of the results on the scientific evidence on the relationship between loneliness and depressive symptoms in older adults shows a positive relationship between the two phenomena. In other words, when feelings of loneliness are more evident and social interaction is reduced, the reporting of symptoms of depressive disorders is greater, and levels of psychological distress are higher. In addition, women and older adults were considered more susceptible to feeling lonely and to depressive symptoms.

The results of this review corroborate findings in literature, which show a prevalence of emotionally 
and socially lonely older adults with high scores on the depression scales used ${ }^{8,9,16}$, with higher rates of psychological distress ${ }^{22}$, which indicate possible depression or a depressive episode, predicting social and emotional loneliness ${ }^{23}$. Loneliness and depressive symptoms are therefore found in directly proportional quantities ${ }^{24}$.

The analysis of the results corroborated results in literature by identifying loneliness as one of the main psychosocial risk factors for the development of depressive symptoms in older adults ${ }^{10,11}$ processing negative stimuli ${ }^{25}$. In addition, it revealed mediating factors between emotional loneliness and obtaining a high score on the depression scales, where life events that cause loneliness predispose the individual to depressive symptoms, while depressive symptoms result in social isolation, causing loneliness. Other risk factors identified by the results and evidenced in literature were: loss of spouse $e^{12,17,26}$, isolation or helplessness and separation from family members, as in the empty nest syndrome ${ }^{13}$, the absence of a partner and not providing care to grandchildren ${ }^{18}$. All of these are factors that cause emotional loneliness, which results in depressive symptoms, which in turn causes social loneliness through the deprivation of social contacts. However, an increase in social relationships leads to a reduction in depressive symptoms ${ }^{27}$.

Social and emotional loneliness have significant effects on depressive symptoms, as older adults who do not receive visits have higher loneliness scores ${ }^{28}$, contributing to depressive symptoms ${ }^{29}$. Older adults themselves characterize loneliness as a precursor to depression and anxiety ${ }^{19}$, and are related to feelings of emptiness and negative emotions ${ }^{30}$.

In addition, women had higher average levels of psychological distress, revealing a greater tendency to develop depressive symptoms than men $^{31}$, which in turn is related to their experiences of loneliness ${ }^{20}$. Increased mortality rates, meanwhile, were related to depression combined with feelings of loneliness ${ }^{14,21}$, especially in men ${ }^{21}$. The scientific evidence confirmed by the results of this review shows that these phenomena are not time-related and are more related to the psychosocial conjuncture of older adults ${ }^{32}$. Furthermore, they can be predictive aspects of suicidal behavior ${ }^{33}$.
In addition, it was found in literature that only the most severe and persistent depressive symptoms are associated with loneliness ${ }^{34}$. It is understood that these are associated and complex phenomena, and so the research team behind this review stress the importance of long-term evaluations and follow-up for a better understanding of these phenomena and their relationships.

It can therefore be said that loneliness does not necessarily cause depressive symptoms, as there are older adults who feel lonely and do not have depression ${ }^{15}$. However, it can be stated that older depressive adults have a higher risk of feeling lonely ${ }^{35}$.

The contributions of this review are related to its presentation of the relationship between loneliness and depressive symptoms, common phenomena in the existential reality of older adults, which contribute to the understanding of this scenario and can serve as guidelines for planning and implementing actions to promote mental health and the prevention of harm to the general health of this population, based on the premises listed. It is also believed that scientific evidence has been produced that is capable of collaborating with decision-making in healthcare practices for older adults through the interdisciplinary and interprofessional approach of the observation and active identification of lonely older adults and/or those who present depressive symptoms.

As a limitation of the present study, some articles in the sample carried out their analyzes considering the older population combined with middle-aged adults. Thus, it is suggested that further investigations are carried out on the relationship between loneliness and depression comparing the two populations.

\section{CONCLUSION}

The present integrative review provides an overview of the relationship between loneliness and depressive symptoms in older adults. Scientific evidence shows that lonely older adults have more depressive symptoms, and loneliness is associated with a feeling of emptiness and negative emotions. Thus, the relationship between these variables is 
that loneliness is considered a high risk factor for depressive symptoms, and therefore for depression. It was also found that women and long-lived older adults are more susceptible to feeling lonely and depressive symptoms.

In addition, loneliness and depressive symptoms can be considered factors that develop jointly due to the similarities of the symptoms that cause them, so when exhibiting depressive symptoms, loneliness can develop, and vice versa. Furthermore, it can be said that there is a cycle between the variables, in which emotional loneliness predisposes the individual to depressive symptoms, which in turn stimulates loneliness.

\section{REFERENCES}

1. Mendes JLV, Cardoso SS, Rumão SG, Rodrigues SNA. O Aumento da população idosa no Brasil e o envelhecimento nas últimas décadas: uma revisão da literatura. Rev Educ Meio Ambiente Saúde. 2018;8(1):13-26.

2. Organização Panamericana de Saúde; Organização Mundial de Saúde. Folha informativa - depressão [acesso em 06 out. 2018]. Disponível em: https:// www.paho.org/bra/index.php?option=com_con tent $\&$ view $=$ article $\&$ id $=5635$ :folha-informativadepressao\&Itemid $=1095$

3. Oliveira DVD, Pivetta NRS, Oliveira GVDND, Silva DAD, Nascimento Júnior JRAD, Cavaglieri CR. Fatores intervenientes nos indicativos de depressão em idosos usuários das unidades básicas de saúde de Maringá, Paraná, 2017. Epidemiol Serv Saúde. 2019;28(3):e2018043 [10 p.].

4. Associação Americana de Psiquiatria. Manual Diagnóstico e Estatístico de Transtornos Mentais. $5^{\mathrm{a}}$. ed. Porto Alegre: ARTMED; 2014.

5. Pinheiro AAA, Tamayo A. Conceituação e definição de solidão. Rev Psicol. 1984;1(2):29-37.

6. Faísca LR, Afonso RM, Pereira H, Patto MAV. Solidão e sintomatologia depressiva na velhice. Anál Psicol. 2019;37(2):209-22.

7. Liberati A, Altman D, Tetzlaff J, Mulrow C, Gotzsche P, Loannidis, et al. The PRISMA statement for reporting systematic reviews and meta-analyses of studies that evaluate healthcare interventions. BMJ. 2009;339:1-28.
Thus, the present study shows how important the duty of primary care health professionals is in observing and actively identifying older adults who meet one of the conditions described, in addition to encouraging greater social participation in the community, implementing activities to monitor the health of older adults in care units, while contributing to reducing their social isolation.

Given the above, the scientific evidence produced can contribute to the improvement of activities for older adults living in the community, focusing on the mental health of the older population.

Edited by: Ana Carolina Lima Cavaletti
8. Alpass FM, Neville S. Loneliness, health and depression in older males. Aging Ment Health. 2003;7(3):212-6.

9. Aylaz R, Aktürk Ü, Erci B, Öztürk H, Aslan H. Relationship between depression and loneliness in elderly and examination of influential factors. Arch Gerontol Geriatr. 2012;55(3):548-54.

10. Li J, Theng YL, Foo S. Depression and psychosocial risk factors among community-dwelling older adults in Singapore. J Cross Cult Gerontol. 2015;30(4):409-22.

11. Chou KL, Chi I. Prevalence and correlates of depression in chinese oldest old. Int J Geriatr Psychiatr. 2004;20(1):41-50.

12. Navarro JR, Leon JB, Olazaran KAP. Depression in the aging: an important health problem in Mexico. Am Lat Hoy Rev Cienc Soc. 2015;71:103-18.

13. Wang G, Hu M, Xiao S, Zhou L. Loneliness and depression among rural empty-nest elderly adults in Liuyang, China: a cross-sectional study. BMJ Open. 2017; 7(10):e016091 [8 p.].

14. Stek ML, Vinkers DJ, Gussekloo J, Beekman ATF, Van Der Mast RC, Westendorp RG. Is depression in old age fatal only when people feel lonely? Ame J Psychiatr. 2005;162(1):178-80.

15. Adams KB, Sanders S, Auth EA. Loneliness and depression in independent living retirement communities: risk and resilience factors. Aging Mental Health. 2004;8(6):475-85.

16. Chou KL, Chi I, Boey KW. Determinants of depressive symptoms among elderly Chinese living alone. Clin Gerontol. 2000;20(4):15-27. 
17. Fried EI, Bockting C, Arjadi R, Borsboom D, Amshoff M, Cramer AOJ, et al. From loss to loneliness: the relationship between bereavement and depressive symptoms. J Abnorm Psychol. 2015;124(2):256-65.

18. Tsai FJ, Motamed S, Rougemont A. The protective effect of taking care of grandchildren on elders' mental health? Associations between changing patterns of intergenerational exchanges and the reduction of elders' loneliness and depression between 1993 and 2007 in Taiwan. BMC Public Health. 2013;13(1):1-9.

19. Barg FK, Ashmore RH, Wittink MN, Murray GF, Bogner HR, Gallo JJ. A mixed-methods approach to understanding loneliness and depression in older adults. J Gerontol Ser B Psychol Sci Soc Sci. 2006;61(6):329-39.

20. Tiikkainen P, Heikkinen RL. Associations between loneliness, depressive symptoms and perceived togetherness in older people. Aging Ment Health. 2005;9(6):526-34.

21. Holwerda TJ, van Tilburg TG, Deeg DJH, Schutter $\mathrm{N}$, Van R, Dekker J, et al. Impact of loneliness and depression on mortality: results from the Longitudinal Ageing Study Amsterdam. Br J Psychiatr. 2016;209(2):127-34.

22. Paul C, Ayis S, Ebrahim S. Psychological distress, loneliness and disability in old age. Psychol Health Med. 2006;11(2):221-32.

23. Power JM, Hannigan C, Hyland P, Brennan S, Kee F, Lawlor BA. Depressive symptoms predict increased social and emotional loneliness in older adults. Aging Ment Health. 2018;24(1):110-8.

24. Houtjes W, van Meijel B, van de Ven PM, Deeg $\mathrm{D}$, van Tilburg T, Beekman A. The impact of an unfavorable depression course on network size and loneliness in older people: a longitudinal study in the community. Int J Geriatr Psychiatr. 2014;29(10):1010-7.

25. Wong NML, Liu HL, Lin C, Huang CM, Wai YY, Lee $\mathrm{SH}$, et al. Loneliness in late-life depression: structural and functional connectivity during affective processing. Psychol Med. 2016;46(12):2485-99.
26. Dahlberg L, Andersson L, McKee KJ, Lennartsson C. Predictors of loneliness among older women and men in Sweden: A national longitudinal study. Aging Ment Health. 2014;19(5):409-17.

27. Ramos M, Wilmoth J. Social relationships and depressive symptoms among older adults in southern Brazil. J Gerontol Ser B Psychol Sci Soc Sci. 2003;58(4):253-61.

28. Castro M, Amorim I. Qualidade de vida e solidão em idosos residentes em lar. Rev Port Enferm Saúde Ment. 2016;(Spe 3):39-44.

29. Barroso SM, Baptista MN, Zanon C. Solidão como variável preditora na depressão em adultos. Est Interdiscipl Psicol. 2018;9(3):26-37.

30. Kvaal K, Halding AG, Kvigne K. Social provision and loneliness among older people suffering from chronic physical illness. A mixed methods approach. Scand J Caring Sci. 2013;28(1):104-11.

31. Conde-Sala JL, Olmo JG, Perxas LC, Garriga OT, Franch JV, et al. Course of depressive symptoms and associated factors in people aged 65+ in Europe: a two-year follow-up. J Affect Dis. 2019;245:440-50.

32. Santos ADS, Santos VDA, Albino A, Silveira RED, Nardelli GG. Sobre a psicanálise e o envelhecimento: focalizando a produção científica. Psicol Teor Pesqui. 2019;35:e35423 [8 p.].

33. Sousa GSD, Perrelli JGA, Mangueira SDO, Sougey EB. Validação por especialistas do Diagnóstico de Enfermagem Risco de suicídio em idosos. Rev Bras Enferm. 2019;72:111-8.

34. Holvast F, Burger H, de Waal MMW, van Marwijk HWJ, Comijs HC, Verhaak PFM. Loneliness is associated with poor prognosis in late-life depression: longitudinal analysis of the Netherlands study of depression in older persons. J Affect Dis. 2015;185:1-7.

35. Fernandes S, Davidson JGS, Guthrie DM. Changes in social engagement and depression predict incident loneliness among seriously ill home care clients. Palliat Support Care. 2017;16(2):170-9. 